\title{
Teacher Monitoring Application in Teaching Based on CodeIgniter Framework in High Schools
}

\author{
Syahri Susanto ${ }^{1}$ \\ School of oil Technic \\ Akademi MInyask dan Gas Balongan \\ syahri28@gmail.com
}

\author{
Bayu Priyatna ${ }^{2}$ \\ Information Systems Study Program \\ School of Engineering and Computer Science \\ Universitas Buana Perjuangan Karawang \\ bayu.priyatna@ubpkarawang.ac.id
}

\author{
Fakhreza Aditya Permana ${ }^{3}$ \\ Information Systems Study Program \\ School of Engineering and Computer Science \\ Universitas Buana Perjuangan Karawang \\ Aditya.fakhreza@gmail.com
}

\begin{abstract}
This is Teacher monitoring in teaching at one Karawang Middle School, is needed to monitor teachers in teaching in class so it can be seen whether the teacher often does teaching and learning activities or not, teachers do not always attend school then carry out teaching and learning activities and also not teachers are not in attendance does not give assignments as a substitute for learning. This monitoring application can support the teacher monitoring process in teaching in the classroom. The system development method used is a waterfall and uses PHP and MySQL. This application is a consideration of how often the teacher teaches in class.
\end{abstract}

Keywords-Monitoring Application, Teaching Teachers, Php and Mysql.

\section{INTRODUCTION}

I need monitoring to get facts, data, and information from an activity that has been carried out. This monitoring intends to see whether the teacher's performance in carrying out teaching activities is going well so I can see it how often each teacher in carrying out teaching activities in Class. Monitoring the Curriculum Work Unit, monitoring the teaching activities of teachers in the Classroom. monitoring by involving the picket teacher as a direct observer of teaching activities carried out by the teacher so that, the picket teacher gives an indicator value to each teacher under the existing indicator criteria. I will take the results of the monitoring into consideration for the next semester's curriculum for the provision of teaching hours to each teacher after seeing the teacher's activeness in teaching in the classroom in the current semester. This research produces a website-based application that can help in the monitoring process that is carried out through the website.

\section{THEORETICAL BASIS}

\section{A. Software engineering}

Software engineering is an engineering discipline or engineering that deals with all aspects of making software that requires following a systematic and approach and using appropriate tools and techniques under the problem to be solved, development constraints and resources [1].

\section{B. Monitoring}

To get an implementation plan is following what is planned management must prepare a program that is monitoring, monitoring will be aimed at getting facts, data and information about implementing the program, whether carrying out activities following what has been planned. The findings of the monitoring results are information for the evaluation process so that the results are whether the programs that are established and implemented get the results or not. Monitoring is an activity to find out I made whether the program that is going well as it should be as planned, are there obstacles that occur and how the program implementers overcome these obstacles [2].

\section{Website}

Website is one application that contains multimedia documents (text, images, sound, animation, video) in it that uses the HTTP protocol (hypertext transfer protocol) and to access it using a software called a browser [3].

\section{Unified Modeling Language (UML)}

UML (Unified Modeling Language) is a modeling language for systems or software that is an object-oriented paradigm. Modeling (modeling) In analyzing and discussing a database, UML (Unified Modeling Language) diagrams can be used. UML is one of the modeling tools to complete object-oriented software modeling [4].

\section{RESEARCH METHODS}

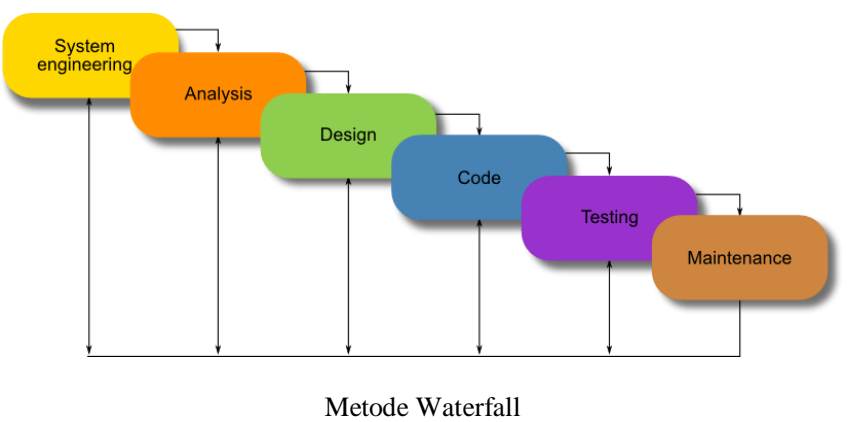

Software Waterfall Method In this research. The study used the waterfall system development method. Where the method has 5 stages in developing the system. The following are the stages of system development in research.

1. Design

The design is used to make an initial description of the application to be made, in system modeling, web-based 
teacher monitoring application interface at High Scchool 1 Karawang.

2. Making the program code

At this stage, the authors do the application coding following the design that has been made.

3. Testing

They carry the test out to test both and of the application that has been made, to ensure the application is running. In this study, testing using the black box testing method.

4. Maintenance

I do maintenance after the application runs by checking the application running.

\section{RESULT AND DISCUSSION}

A. Use Case Proposed Application Diagram

In this diagram will discuss what is in this application and who can use it.

1. Use case diagram application proposal for access rights to the Monitoring and Evaluation Section.

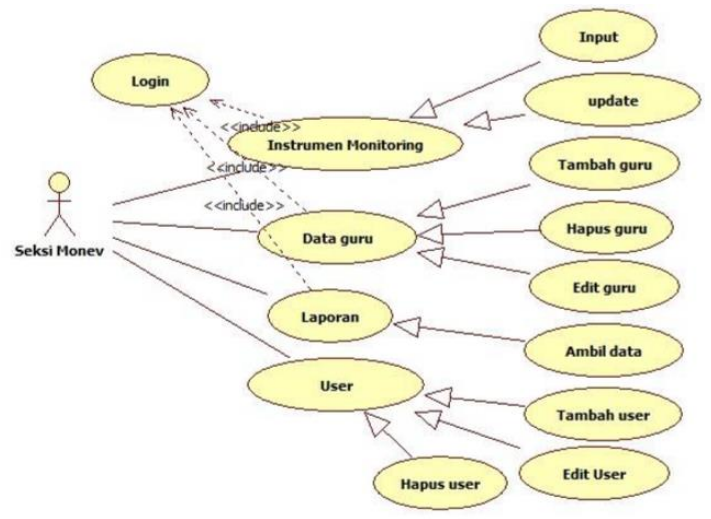

Fig 2. Use case diagram application proposals for access rights to the Monitoring and Evaluation Section

\section{B. Activity Diagram}

Application Proposed Activity diagram illustrates the workflow or work activities of the application to be implemented. The following is an activity diagram of the proposed application that will be implemented.

1. Activity diagram application proposal for access rights to the Monitoring and Evaluation Section;

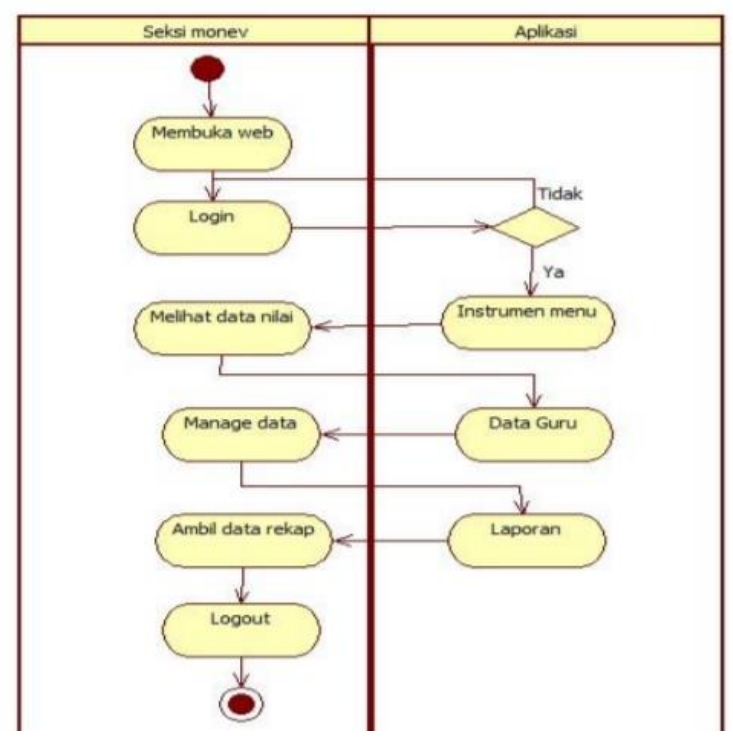

Fig 3. Activity diagram application proposal for access rights to the Monitoring and Evaluation Section

2. Activity diagram application proposal for teacher picket access rights.

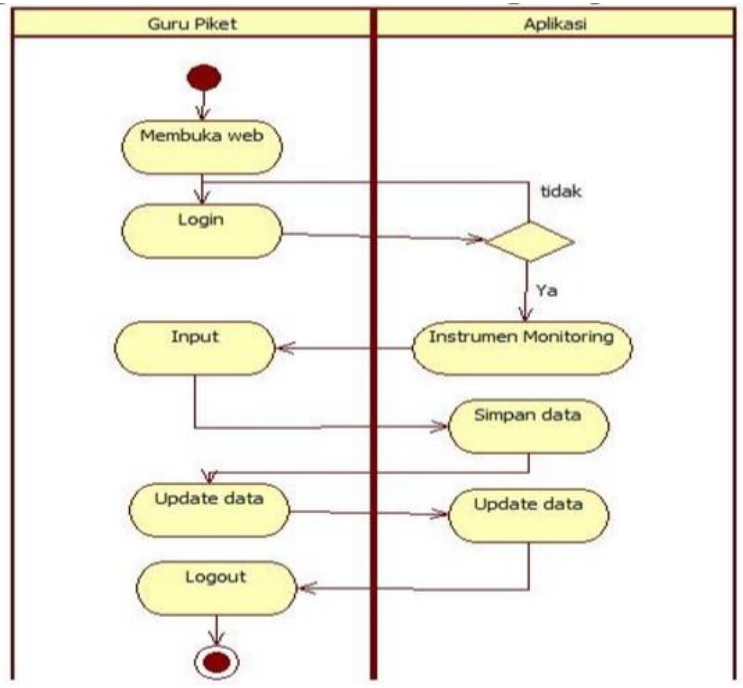

Fig 4. Activity diagram application proposal for access rights to the Monitoring and Evaluation Section

\section{Class Diagram}

Application Proposal Class diagrams are used to describe the relationship between classes of a system. The following class diagram of the monitoring application.

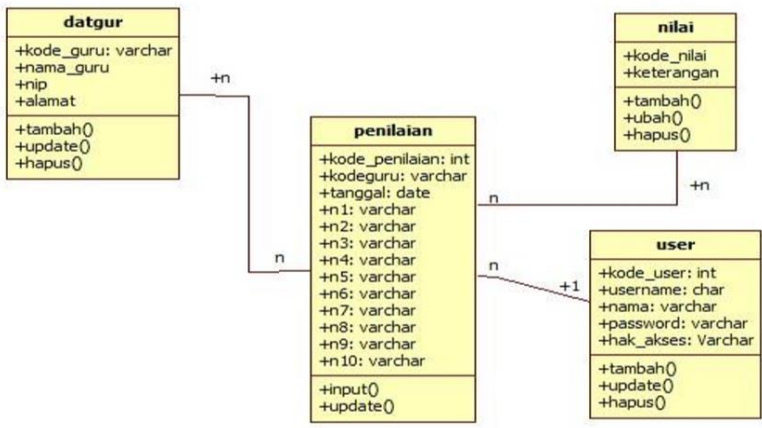

Fig 5. Class diagram 
D. Proposed Application Interface Design

1. Login interface design

To create interaction between user and application in login, the login interface design will later interact with the login process between user and application.

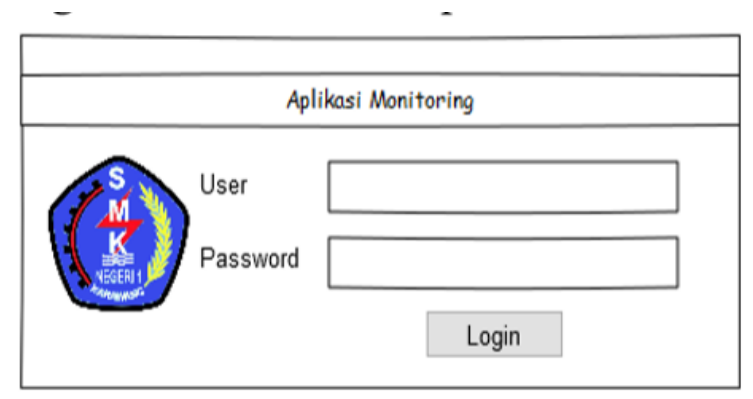

Fig 6. Login interface design

2. The interface design of Teacher Picket Access Rights

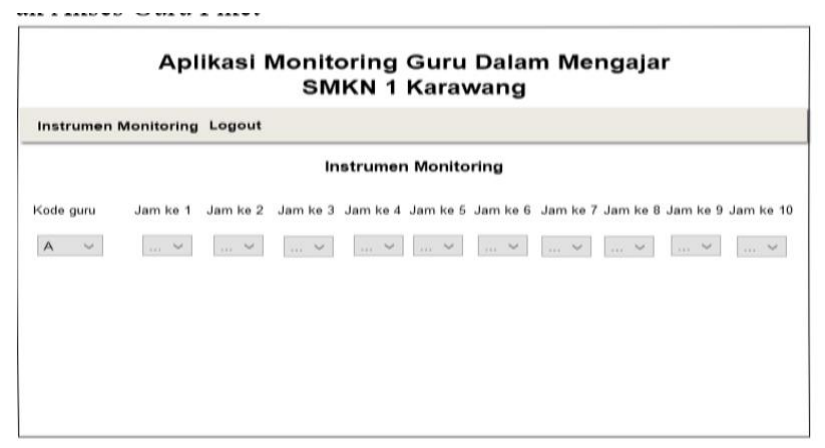

Fig 7. Interface design of Teacher Picket Access Rights

3. The interface design of M\&E Section Access Rights

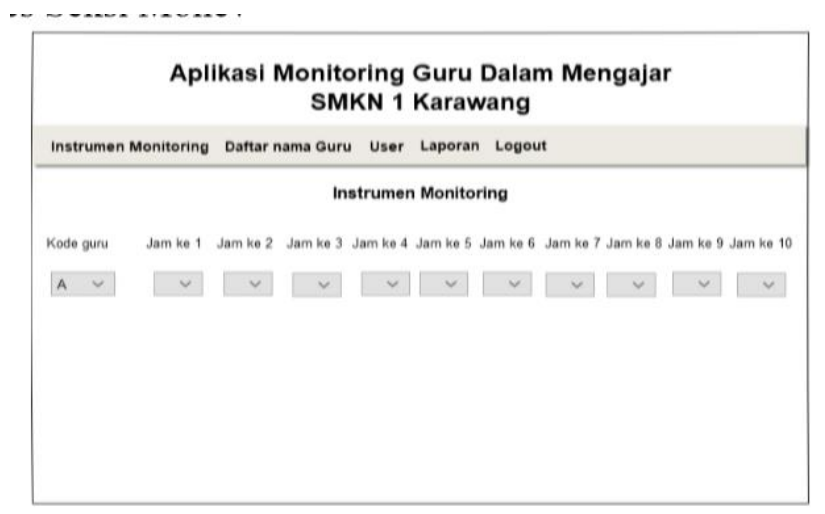

Fig 8. Interface design of M\&E

\section{E. Implementation}

This implementation contains the results of the design that has been created. The following is the display application.
2. Interface the main page

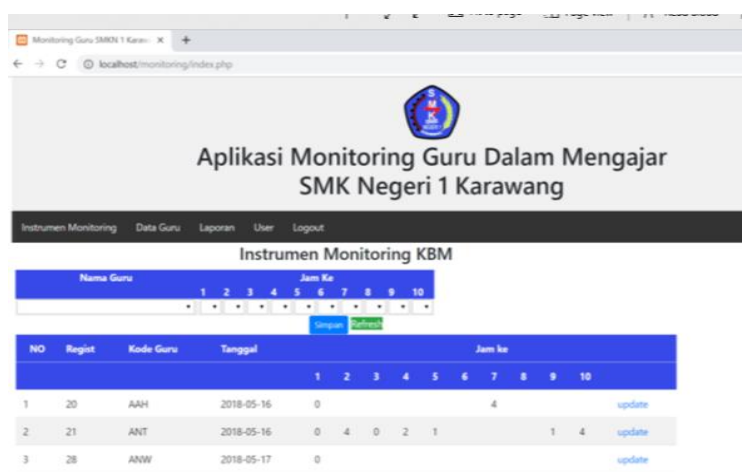

Fig 9. Main Page

\section{CONCLUSION}

They base the conclusion on the analysis that has been carried out as follows.

1. The teacher monitoring system in teaching at the Karawang high school one work unit is still manual, in inputting indicators that are still manual so they are prone to errors.

2. In the monitoring application proposed by the author, a monitoring instrument input form is provided which is stored into the database and data from the inputted values can be seen.

3. The process of the report can be taken following the needs of the report date.

\section{REFERENCES}

[1] B. P. April Lia Hananto, "Rancang Bangun Aplikasi Informasi Harga Produk," TechnoXplore, vol. 2, no. 1, pp. 10-20, 2017.

[2] Arisantoso., Sanwasih, Moch., Samsudin, Didin Adhuri. 2014. Prototipe monitoring dan evaluasi kinerja dosen untuk menunjang kegiatan tridharma perguruan tinggi (studi kasus universitas islam attahiriyah). Teknologi Informasi Dan Multimedia. ISSN: 2302-3805.

[3] Handayani, Sutri. 2018. Perancangan sistem informasi penjualan berbasis e-commerce studi kasus toko kun jakarta. Ilkom Jurnal Ilmiah. Vol. 10. E-ISSN 2548-7779.

[4] Pranata, Dana., \& Hamdani., \& K, Marisa, Dyna. 2015. Rancang bangun website jurnal ilmiah bidang komputer (Studi Kasus : Program Studi Ilmu Komputer Universitas Mulawarman). Jurnal Informatika Mulawarman.Vol.10.

[5] Riyalda, Bondan F., \& Turyana Iyan., \& Santoso Eko W. 2018. Sistem informasi bencana tanah longsor (sibenar) berbasis web kecamatan cililin, kabupaten bandung barat. Jurnal Alami. Vol. 2. EISSN: 2548-8635.

[6] Suhartanto, Medi. 2012. Pembuatan website sekolah menengah pertama negeri 3 delanggu dengan 
menggunakan php dan mysql. Sentra pendidikan engineering dan Edukasi. Vol. 4. ISSN: 2088-0154. 